\title{
METODE DECISION TREE UNTUK PEMBUKAAN CABANG BARU DENTAL CARE \& AESTHETIC CENTER
}

\author{
Eka Sri Rahayu \\ Sekolah Tinggi Ilmu Ekonomi Bisnis Indonesia, Jakarta; \\ Haryadi Sarjono \\ Binus Business School, Binus University, Jakarta Barat, \\ e-mail : haryadi_s@binus.edu
}

\begin{abstract}
This study aims to predict the number of patients visiting Dental Care \& Aesthetic Center, Jln. Taman Ratu blok BB1, No. 2A, Jakarta Barat, with the analysis technique used is to use a forecasting method approach consisting of seven methods namely moving average, exponential smoothing, trend projection, additive decomposition, average all, additive decomposition CMA multiplicative decomposition average all, multiplicative decomposition CMA, and period from January 2017 to September 2018. From the results of the research using seven forecasting methods, the smallest MAD is 39.66634 and the smallest MSE is 2.305.762, in the multiplicative decomposition average all method showed that the data showed the forecasting of the number of patients visiting Dental Care \& Aesthetic Center in the October 2018 period amounting to 293,0451 patients. In addition, in this study the decision tree method is used for making alternative decisions which should be done by the company, the result of decision making using decision trees is to open a new branch in the Menteng area, Central Jakarta.
\end{abstract}

\begin{abstract}
ABSTRAK
Penelitian ini bertujuan untuk memprediksi jumlah pasien yang mengunjungi Dental Care \& Aesthetic Center, Jln. Taman Ratu blok BB1, No. 2A, Jakarta Barat, dengan teknik analisis yang digunakan adalah dengan menggunakan pendekatan metode peramalan yang terdiri dari tujuh metode yaitu moving average, exponential smoothing, proyeksi tren, dekomposisi aditif, rata-rata semua, dekomposisi aditif CMA multiplikasi dekomposisi rata-rata semua, multiplikasi dekomposisi CMA, dan periode dari Januari 2017 hingga September 2018. Dari hasil penelitian menggunakan tujuh metode peramalan, MAD terkecil adalah 39.66634 dan UMK terkecil adalah 2.305.762, dalam rata-rata dekomposisi multiplikasi semua metode menunjukkan bahwa data menunjukkan perkiraan jumlah pasien mengunjungi Dental Care \& Aesthetic Center pada periode Oktober 2018 berjumlah 293.0451 pasien. Selain itu, dalam penelitian ini metode pohon keputusan digunakan untuk membuat keputusan alternatif yang harus dilakukan oleh perusahaan, hasil pengambilan keputusan menggunakan pohon keputusan adalah membuka cabang baru di daerah Menteng, Jakarta Pusat.
\end{abstract}

Kata Kunci : Center, Decision Tree, MAD, MSE.

\section{PENDAHULUAN}

Kebutuhan masyarakat akan manusia pernah jatuh sakit, oleh karena kesehatan di zaman sekarang semakin itu, usaha yang berhubungan dengan meningkat. Maklum saja, hampir semua kesehatan akan selalu dibutuhkan. 
Kesadaran masyarakat yang semakin tinggi akan pentingnya kesehatan merupakan salah satu alasan bahwa kebutuhan akan prasarana kesehatan juga semakin meningkat. Selain itu masyarakat juga akan semakin pintar dalam memilih jasa penyedia pelayanan kesehatan yang terbaik sesuai dengan apa yang mereka inginkan dan butuhkan.

Berikut beberapa alasan peneliti memilih sektor industri kesehatan gigi dan mulut :

1. Presentase penduduk yang mempunyai masalah kesehatan gigi dan mulut menurut Riskesdas tahun 2007 dan 2013 meningkat dari 23,2\% menjadi 25,9\%. Dari penduduk yang mempunyai masalah kesehatan gigi dan mulut, presentase penduduk yang menerima perawatan medis gigi meningkat dari 29,7\% tahun 2007 menjadi $31,1 \%$ pada tahun 2013. (www.depkes.go.id, 2014)

2. Bisnis estetika gigi memang hampir tidak ada matinya. Beberapa tahun terakhir pemakaian behel gigi dan bleaching (pemutihan gigi) merambah luas dari kalangan atas hingga kalangan menengah ke bawah. Setiap remaja seakan berlomba-lomba memagari giginya, walaupun alasan kesehatan bukan lagi nomor satu. Tapi malah lebih untuk sekadar gaya. (www.swa.co.id, 2015)

3. Didorong oleh kebutuhan untuk mengatasi kebutuhan yang besar akan prasarana dan sumber daya manusia, belanja untuk keperluan kesehatan diperkirakan akan meningkat sebesar $10,7 \%$ per tahun pada pasar pertumbuhan ekonomi pesat dibandingkan dengan pasar negaranegara maju yang hanya meningkat $3,7 \%$ pada tahun 2022. (www.swa.co.id, 2017).

Jakarta adalah ibukota negara Indonesia, di balik kesibukan aktivitasnya, Jakarta menyimpan banyak potensi ekonomi dan infrastruktur tersembunyi. meskipun kota padat penduduk, Jakarta adalah kota yang paling diincar untuk investasi properti dibandingkan Shanghai, Singapura, maupun Kuala Kumpur. Berikut ini adalah 10 kota yang mempunyai ekonomi terbesar di Indonesia berdasarkan data Badan Pusat Statistik (BPS) yang dikutip detikFinance, Selasa $(9 / 5 / 2017)$

Daftar 10 Kota dengan Ekonomi Terbesar di Indonesia

\begin{tabular}{clrrlr}
\hline & Nama Kota & Persentase & No & Nama Kota & Persentase \\
No & & & & & 1,43 \\
\hline 1 & DKI Jakarta & 16,95 & 6 & Karawang & 1,41 \\
2 & Surabaya & 3,48 & 7 & Medan & 1,25 \\
3 & Bekasi & 2,11 & 8 & Sidoarjo & 1,16 \\
4 & Bandung & 1,68 & 9 & Bengkalis & 1,15 \\
5 & Bogor & 1,44 & 10 & Semarang &
\end{tabular}

Sumber: detik.com (2017)

Dari tabel diatas dapat diketahui bahwa khusus Jakarta, menguasai setidaknya 16,95\% ekonomi Indonesia pada 2015.
Kota Jakarta Barat merupakan bagian dari Provinsi DKI Jakarta yang merupakan wilayah padat penduduk, 
Distribusi dan Kepadatan Penduduk Menurut Kabupaten/Kota di Provinsi DKI Jakarta Tahun 2015

\begin{tabular}{clcc}
\hline No & Kabupaten/Kota & \% Penduduk & $\begin{array}{c}\text { Kepadatan Penduduk } \\
\text { Per-Km2 }\end{array}$ \\
\hline 1 & Kepulauan Seribu & 0,23 & $2.683,96$ \\
2 & Jakarta Selatan & 21,48 & $15.472,17$ \\
3 & Jakarta Timur & 27,94 & $15.124,15$ \\
4 & Jakarta Pusat & 8,98 & $18.993,11$ \\
5 & Jakarta Barat & 24,20 & $19.017,92$ \\
6 & Jakarta Utara & 17,17 & $11.913,83$ \\
& DKI Jakarta & $\mathbf{1 0 0}$ & $\mathbf{8 3 . 2 0 5 , 6 8}$ \\
\hline
\end{tabular}

Sumber:www.jakarta.bps.go.id (2015)

Berdasarkan tabel diatas terlihat Jakarta Barat memiliki angka kepadatan penduduk paling tinggi, sehingga penelitian dilakukan di daerah tersebut.

Jumlah Tempat Praktek Dokter Gigi menurut Kecamatan di Jakarta Barat

\begin{tabular}{clcc}
\hline No. & Kecamatan & $\begin{array}{c}\text { Praktek Dokter Gigi } \\
\text { Tunggal }\end{array}$ & $\begin{array}{c}\text { Praktek Dokter Gigi } \\
\text { Bersama }\end{array}$ \\
\hline 1. & Kembangan & 100 & 26 \\
2. & Kebon Jeruk & 131 & 26 \\
3. & Palmerah & 53 & 10 \\
4. & Grogol Petamburan & 147 & 37 \\
5. & Tambora & 42 & 9 \\
6. & Taman Sari & 31 & 7 \\
7. & Cengkareng & 72 & 15 \\
8. & Kalideres & 50 & 32 \\
& Total & $\mathbf{6 2 6}$ & $\mathbf{1 6 2}$ \\
& 2012 & 265 & 154 \\
& 2011 & 94 & 1 \\
\hline
\end{tabular}

Sumber: www.jakbarkota.bps.go.id (2013)

Dapat dilihat dari tabel di atas, Kecamatan Kebon Jeruk terdapat 131 parktek dokter gigi tunggal yaitu terbanyak kedua setelah kecamatan Grogol Petamburan, dan terdapat 26 praktek dokter gigi bersama, terbanyak ketiga setelah kecamatan Grogol
Petamburan dan kecamatan Kalideres. Masyarakat cenderung lebih menuntut pelayanan kesehatan yang lebih baik dan cepat, hal ini menjadikan persaingan yang semakin ketat. 


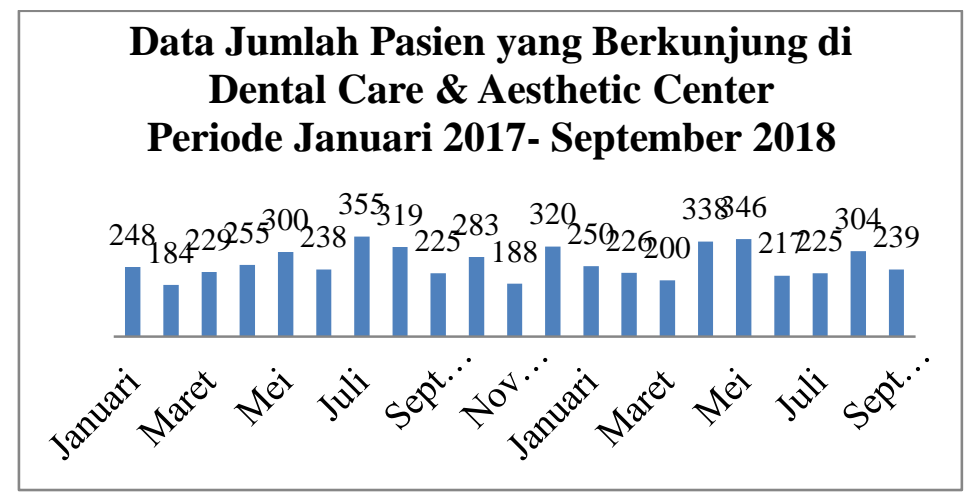

Sumber: Klinik Dental Care \& Aesthetic Center (2018)

Berdasarkan Gambar diatas, grafik tentang data jumlah pasien, dari Klinik Dental Care \& Aesthetic Center mulai bulan Januari 2017 sampai dengan bulan September tahun 2018 mengalami naik turun jumlah pasien yang tidak pasti.

Berdasarkan uraian permasalah diatas maka diambil perumusan masalah sebagai berikut :

1. Dari data sebelumnya berapa jumlah pasien yang berkunjung ke Klinik Dental Care \& Aesthetic Centre, Taman Ratu Blok BB1, No 2A, Jakarta Barat periode tahun 2018 dengan metode forecasting ?

2. Apakah keputusan pihak manajemen untuk mengatasi jumlah pasien yang berkunjung diluar perkiraan ?

3. Sistem peramalan apakah yang digunakan pihak manajemen agar peramalan jumlah pasien yang yang berkunjung lebih lebih efektif dan efisien?

4. Dengan jumlah pasien yang semakin banyak, apakah memungkinkan untuk membuka cabang lain, di daerah sekitar Jakarta?

Metode peramalan dapat digunakan untuk menganalisa pola dari data masa lalu dalam memprediksi kebutuhan yang diperlukan di masa yang akan datang, sehingga dapat memberikan proyeksi permintaan yang sistematis. Ada beberapa definisi peramalan menurut para ahli, antara lain:

1. Menurut Heizer \& Render (2017:113), peramalan adalah suatu seni dan ilmu pengetahuan dalam memprediksi peristiwa masa mendatang.

2. Menurut Athoillah (2010:26), artinya meramal atau memperkirakan sesuatu yang akan terjadi dimasa yang akan datang berdasarkan berbagai kemungkinan.

3. Menurut Sarjono dalam Sarjono dan Abbas (2017:15), peramalan adalah memprediksi sesuatu yang akan datang dengan perhitungan data historis. 
Perbandingan Model Forecasting

\begin{tabular}{|c|c|c|c|}
\hline \multirow{2}{*}{ Variabel } & \multicolumn{3}{|c|}{ Model Forecasting } \\
\hline & Kualitatif & Time Series & Causal \\
\hline Data & $\begin{array}{l}\text { Data diperoleh dari } \\
\text { peristiwa masa lalu } \\
\text { berupa pernyataan } \\
\text { secara subyektif }\end{array}$ & $\begin{array}{l}\text { Data diperoleh dari } \\
\text { data historis pada } \\
\text { urutan titik-titik data } \\
\text { yang berjarak sama } \\
\text { dalam waktu } \\
\text { (mingguan, bulanan, } \\
\text { kuartalan dan lain- } \\
\text { lain) }\end{array}$ & $\begin{array}{l}\text { Data diperoleh dari } \\
\text { data historis }\end{array}$ \\
\hline $\begin{array}{l}\text { Sifat } \\
\text { Model }\end{array}$ & Subyektif & Obyektif & Obyektif \\
\hline Hasil & $\begin{array}{l}\text { Hasil dari metode } \\
\text { kualitatif ini terlihat } \\
\text { kurang ilmiah, } \\
\text { namun dapat } \\
\text { memberi hasil yang } \\
\text { baik }\end{array}$ & $\begin{array}{l}\text { Hasil dari metode time } \\
\text { series adalah hasil } \\
\text { perhitungan yang } \\
\text { ilmiah }\end{array}$ & $\begin{array}{l}\text { Hasil dari metode } \\
\text { causal adalah hasil } \\
\text { dari pertimbangan } \\
\text { beberapa faktor atau } \\
\text { variabel-variabel } \\
\text { yang bisa } \\
\text { mempengaruhi } \\
\text { jumlah yang sedang } \\
\text { diramalkan, metode } \\
\text { ini menggunakan } \\
\text { pendekatan sebab- } \\
\text { akibat }\end{array}$ \\
\hline
\end{tabular}

Sumber: Kumpulan data yang diolah oleh peneliti (2018)

\section{Pengertian Pohon Keputusan (Decison}

Tree)

Menurut Widodo (2013:21), pohon keputusan (Decision Tree) merupakan salah satu teknik terkenal dalam data mining dan merupakan salah satu metode yang populer dalam menentukan keputusan suatu kasus. Menurut Prasetyo (2014:12), Decision Tree adalah pohon yang digunakan sebagai prosedur penalaran untuk mendapatkan jawaban dari masalah yang dimaksud.

Analisis pohon keputusan dimulai dari arah kanan ke kiri. Pada setiap simpul kejadian, dihitung nilai harapan dari alternatif yang bersangkutan. Pada simpul keputusan, dipilih satu alternatif terbaik (nilai harapan tertinggi atau biaya terendah) dari berbagai alternatif yang ada pada simpul itu.
1. Istilah pada pohon keputusan yang dikemukakan oleh Herjanto (2007:31)

a. Alternatif adalah sebuah tindakan atau strategi yang dapat dipilih oleh seorang pengambil keputusan.

b. Kondisi alami adalah sebuah kejadian atau situasi di mana pengambil keputusan hanya memiliki sedikit kendali atau tidak sama sekali.

2. Simbol yang digunakan dalam sebuah pohon keputusan yang dikemukakan oleh Herjanto (2007:31)

a. $\square$ adalah sebuah titik keputusan di mana terdapat satu alternatif atau lebih yang dapat dipilih.

b. $\bigcirc$ adalah sebuah titik kondisi alami di mana kondisi alami mungkin akan terjadi. 


\section{Jenis-Jenis Lingkungan Pengambilan Keputusan}

Menurut Herjanto (2007:26), terdapat tiga lingkungan pengambilan keputusan yaitu :

1. Pengambilan Keputusan Pembelian Dalam Kondisi Tidak Pasti

Kondisi tidak pasti adalah suatu keadaan yang memenuhi beberapa syarat. Yaitu sebagai berikut:

a. Ada beberapa alternatif tindakan yang fisibel (dapat dilakukan)

b. Nilai probabilitas masing-masing kejadian tidak diketahui

c. Memiliki Pay-off sebagai hasil kombinasi suatu tindakan dan kejadian tidak pasti

Pengambilan Keputusan dalam kondisi tidak pasti adalah pengambilan keputusan dimana terjadi hal-hal sebagai berikut:

1. Tidak diketahui jumlah dan kemungkinan munculnya kondisi tersebut.

2. Pengambil keputusan tidak dapat menentukan probabilitas terjadinya berbagai kondisi atau hasil yang keluar.

3. Yang diketahui hanyalah kemungkinan hasil suatu tindakan, tetapi tidak dapat diprediksi berapa besar probabilitas setiap hasil tersebut.

4. Pengambil Keputusan tidak mempunyai pengetahuan atau informasi lengkap mengenai peluang terjadinya bermacammacam keadaan tersebut.

5. Hal yang akan diputuskan biasanya relatif belum pernah terjadi.

6. Tingkat ketidakpastian keputusan semacam ini dapat dikurangi dengan beberapa cara antara lain :
a. Mencari informasi lebih banyak
b. Melalui riset atau penelitian
c. Menggunakan probabilitas subjektif

Berikut ini adalah beberapa kriteria atau metode teknik penyelesaian pengambilan keputusan dalam kondisi tidak pasti:
1) Kriteria Maximax

Pengambil Keputusan dianggap sangat optimis yaitu dipilihnya hasil-hasil terbesar dari alternatif-alternatif yang memberikan hasil maksimal dalam berbagai keadaan secara alamiah.

2) Kriteria Maximin

Pada kriteria ini, pengambil keputusan dianggap pesimis atau konservatif tentang masa depan. Menurut kriteria ini, hasil terkecil untuk setiap alternatif dibandingkan dengan alternatif yang menghasilkan nilai maksimal dari hasil-hasil minimal yang dipilih atau memilih alternatif yang minimalnya paling besar.

3) Kriteria Laplace (Equal Likelihood)

Menurut kriteria ini, pengambilan keputusan mengasumsikan bahwa probabilitas terjadinya berbagai kondisi adalah sama besarnya. Hasil yang dipilih adalah yang memiliki nilai tertimbang tertinggi.

4) Kriteria Regret (Kriteria Minimax)

Kriteria ini pertama kali diperkenalkan oleh L.J. savage yang didasarkan pada konsep Opportunity Loss atau Regret.

2. Pengambilan Keputusan yang Berisiko Pengambilan keputusan yang mengandung risiko bergantung pada probabilitas. Beberapa kondisi alami mungkin terjadi, masing-masing dengan probabilitas tertentu yang telah diasumsikan. Dengan diberikannya tabel keputusan dengan nilai kondisional dan perkiraan probabilitas untuk semua kondisi alami, nilai harapan moneter (Expected Monetary Value_EMV) untuk setiap alternatif dapat ditentukan.

EMV (Alternatif i) $=($ Hasil kondisi alami 1) $\times$ (Kemungkinan terjadi kondisi alami 1) + (Hasil kondisi alami 2) $\times$ (Kemungkinan terjadi kondisi alami 2) $+\ldots+$ (Hasil kondisi alami terakhir) $\times$ (Kemungkinan terjadi kondisi alami terakhir). 
3. Pengambilan Keputusan dalam Keadaan Pasti

Jika seorang manajer dapat menentukan kondisi alami yang akan terjadi, maka ia akan mengetahui keputusan yang harus diambil. EMV (expected value of perfect information) merupakan kriteria yang paling sering digunakan untuk menganalisis pohon keputusan.

\section{Pengertian Probabilitas}

\section{METODE}

Penelitian ini mengambil lokasi di Dental Care \& Aesthetic Center, Taman Ratu yang beralamat di Jl. Taman Ratu Blok BB1 No.2A Jakarta Barat 11510.

Dalam penelitian ini penulis menggunakan data sekunder sebagai sumber informasi, dimana data tersebut telah terdokumentasi diperusahaan yang sudah tersedia dalam bentuk dokumen daftar pasien yang berkunjung di Klinik dari tahun 2013 sampai dengan 2017.

Dalam penelitian ini agar diperoleh data yang dapat memberikan gambaran masalah yang jelas, relevan dan lengkap, penulis menggunakan metode pengumpulan data sebagai berikut :

a. Mean Absolute Deviation (MAD), menurut Arsyad (1995) dalam Sarjono dan Abbas (2017:21) MAD ini sangat berguna untuk mengukur kesalahan peramalan dalam unit ukuran yang sama seperti data aslinya. MAD digunakan untuk mengetahui apakah hasil perhitungan forecast mendekati atau sama dengan kenyataan dilapangan, oleh karena itu dicari mana MAD yang paling kecil.

b. Mean Squared Error (MSE), menurut Arsyad (1995) dalam Sarjono dan Abbas (2017:21) MSE digunakan untuk mengetahui mana metode yng paling mendekati dengan kebenaran, oleh karena itu dicari MSE yang paling kecil.

Metode Forecasting :
Menurut Sudaryono (2012:3), probabilitas adalah suatu ukuran tentang kemungkinan suatu peristiwa yang akan terjadi dimasa mendatang, probabilitas dinyatakan antara 0 sampai 1 dalam presentase.

\section{QM For Windows}

Menurut Sarjono (2014:G-3), Quantitative Method for Windows adalah paket program komputer untuk membantu menyelesaikan persoalan-persoalan metode kuantitatif, manajemen sains, atau riset operasi.

1) Exponential Smoothing merupakan metode peramalan rata-rata bergerak dengan pembobotan yang canggih, namun masih mudah digunakan.

2) Moving Average mengunakan sejumlah data aktual masa lalu untuk menghasilkan peramalan. Rata-rata bergerak berguna jika kita dapat mengasumsikan bahwa permintaan pasar akan setabil sepanjang masa yang kita ramalkan.

3) Trend Projection, teknik ini menyesuaikan garis kecenderungan dengan rangkaian poin data historis dan kemudian, memproyeksikan kemiringan garis ke dalam permalan masa mendatang atau dalam jangka menengah hingga jangka panjang.

4) Decomposition Techniques, metode peramalan additive decomposition terbagi menjadi dua yakni Additive Decomposition - Average All dan Additive Decomposition - Centered Moving Average. Metode peramalan multiplicative decomposition juga terbagi menjadi 2 yaitu Multiplicative Decomposition - Average All dan Multiplicative Decomposition Centered Moving Average.

Metode Decision Tree yaitu sebagai hasil akhir keputusan dimana ada enam kriteria yaitu Maximax, Maximin, Equal Likelihood, Minimax Regret, Expected Value dan Expected Opportunity Loss yang menghasilkan keputusan dari 
alternatif yang ada, dimana hasilnya diolah

Windows.

secara manual dan program $Q M$ for

\section{ANALISIS DAN PEMBAHASAN}

Data pasien yang berkunjung di klinik Dental Care \& Aesthetic Center periode Januari 2017 sampai dengan September 2018 ditunjukkan pada tabel dibawah ini :

\begin{tabular}{|c|c|c|}
\hline Bulan & Tahun 2017 & Tahun 2018 \\
\hline Januari & 248 & 250 \\
\hline Februari & 184 & 226 \\
\hline Maret & 229 & 200 \\
\hline April & 255 & 338 \\
\hline Mei & 300 & 346 \\
\hline Juni & 238 & 217 \\
\hline Juli & 355 & 225 \\
\hline Agustus & 319 & 304 \\
\hline September & 225 & 239 \\
\hline Oktober & 283 & $?$ \\
\hline November & 188 & \\
\hline Desember & 320 & \\
\hline
\end{tabular}

Sumber: Dental Care \& Aesthetic Center, (2018)

Rekapitulasi Hasil Perhitungan

Dari perhitungan diatas dengan menggunakan 7 metode untuk menentukan hasil mana yang dipilih adalah dengan cara melihat tingkat kesalahan (MAD/MSE) terkecil.

Hasil Rekapitulasi Peramalan Pasien Dental Care \& Aesthetic Center Secara Manual

\begin{tabular}{llrrr}
\hline NO & \multicolumn{1}{c}{ METODE } & MAD & MSE & $\begin{array}{r}\text { FORECASTIN } \\
\text { G }\end{array}$ \\
\hline 1. & Exponential Smoothing & 47,96 & $3.054,62$ & 260,91 \\
2. & Moving Average & 51,68 & $3.903,10$ & 256 \\
3. & Trend Projection & 46,88 & $2.761,02$ & 271,83 \\
4. & Additive Decomposition Average All & 42,07 & $2.420,77$ & 271,83 \\
5. & Additive Decomposition CMA & 42,10 & $2.429,69$ & 271,83 \\
6. & Multiplicative Decomposition Average & $\mathbf{4 1 , 6 2}$ & $\mathbf{2 . 3 7 9 , 8 6}$ & $\mathbf{2 7 1 , 8 3}$ \\
& All & & & \\
7. & Multiplicative Decomposition CMA & 42,15 & $2.405,22$ & 271,83 \\
\hline
\end{tabular}

Sumber : Diolah oleh peneliti, (2018) 
Dengan QM For Windows

\begin{tabular}{clrrr} 
NO & \multicolumn{1}{c}{ METODE } & MAD & MSE & FORECASTING \\
1. & Exponential Smoothing & 47,956 & $3.054,643$ & 260,9066 \\
2. & Moving Average & 57,3519 & $4.336,746$ & 256 \\
3. & Trend Projection & 44,5704 & $2.629,623$ & 270,7524 \\
4. & Additive Decomposition Average All & 40,0188 & $2.308,919$ & 292,5999 \\
5. & Additive Decomposition CMA & 39,9984 & $2.310,365$ & 291,6467 \\
6. & Multiplicative Decomposition Average All & $\mathbf{3 9 , 6 6 3 4}$ & $\mathbf{2 . 3 0 5 , 7 6 2}$ & $\mathbf{2 9 3 , 0 4 5 1}$ \\
7. & Multiplicative Decomposition CMA & 40,2709 & $2.314,096$ & 290,9404 \\
\hline
\end{tabular}

Sumber: Diolah oleh peneliti, (2018)

Dari tabel diatas terlihat bahwa nilai MAD dan MSE terkecil dari perhitungan metode Multiplicative Decomposition CMA baik secara perhitungan manual maupun aplikasi QM For Windows, yaitu dengan nilai MAD sebesar 39,6634 dan MSE sebesar 2.305,762.

\section{Pengolahan Data Decision Tree}

Menyikapi data jumlah pasien yang berkunjung yang berasal dari beberapa daerah, dibawah ini data jumlah pasien yang berkumnjung dari beberapa aerah di Jakarta.

Data Jumlah Pasien Dental Care \& Aesthetic Center (2017-18)

\begin{tabular}{l|r|r|r}
\hline \multicolumn{1}{c|}{ Daerah } & \multicolumn{1}{c|}{$\mathbf{2 0 1 7}$} & $\mathbf{2 0 1 8}$ & \multicolumn{1}{c}{ Total } \\
\hline Jakarta Selatan & 135 & 105 & 240 \\
1. Pancoran & 200 & 215 & 415 \\
2. Kebayoran Baru & 125 & 100 & 225 \\
3. Tebet & 170 & 95 & 265 \\
4. Pasar Minggu & 382 & 154 & 536 \\
5. Setiabudi & $\mathbf{1 . 0 1 2}$ & $\mathbf{6 6 9}$ & $\mathbf{1 . 6 8 1}$ \\
\hline \multicolumn{1}{c}{ Total } & & & \\
\hline Jakarta Utara & 86 & 119 & 205 \\
6. Penjaringan & 79 & 99 & 178 \\
7. Pantai Indah Kapuk & $\mathbf{1 6 5}$ & $\mathbf{2 1 8}$ & $\mathbf{3 8 3}$ \\
\hline \multicolumn{1}{c}{ Total } & 254 & 175 & \\
\hline Jakarta Pusat & 309 & 365 & 629 \\
8. Gambir & 136 & 164 & 674 \\
9. Menteng & 154 & 133 & 287 \\
10. Kemayoran & $\mathbf{8 5 3}$ & $\mathbf{8 3 7}$ & $\mathbf{1 . 6 9 0}$ \\
11. Cempaka Puth & & & \\
\hline \multicolumn{1}{c}{ Total } & 299 & 300 & 599 \\
\hline Jakarta Barat & 220 & 165 & 385 \\
12. Kebon Jeruk & 125 & 166 & 291 \\
13. Taman Sari & 265 & 195 & 460 \\
14. Kalideres & $\mathbf{9 0 9}$ & $\mathbf{8 2 6}$ & $\mathbf{1 . 7 3 5}$ \\
15. Cengkareng & & & \\
\hline \multicolumn{1}{|c|}{ Total } & & & \\
\hline
\end{tabular}

Sumber: Dental Care \& Aesthetic Center (2018)

Tabel diatas terlihat bahwa daerah yang berpotensi dengan jumlah pasien terbanyak adalah Setiabudi, Menteng dan
Kebon Jeruk, dari ketiga daerah tersebut peneliti akan memilih satu daerah untuk membuka cabang baru dengan 
menggunakan metode Decision Tree. Berikut ini adalah tabel biaya yang akan dikeluarkan berdasarkan masing-masing kriteria

Biaya Pembukaan Cabang Baru Dental Care \& Aesthetic Center di Setiabudi pada Kondisi Ekonomi dan Politik Memburuk

\begin{tabular}{|c|c|c|}
\hline No. & Keterangan & Biaya \\
\hline 1. & Pembelian Ruko & Rp.6.550.000.000 \\
\hline 2. & Instalasi listrik, air dan telepon & Rp.59.900.000 \\
\hline 3. & Kursi dan meja tunggu pasien & Rp.98.000.000 \\
\hline 4. & Kursi dan meja front office & Rp.49.000.000 \\
\hline 5. & Lampu ruangan & Rp. 27.500.000 \\
\hline 6. & Almari & Rp.28.100.000 \\
\hline 7. & Set komputer & Rp.279.000.000 \\
\hline 8. & Alat tulis kantor (buku, bolpoin dan lain lain) & Rp.8.500.000 \\
\hline 9. & Kompressor bahan dokter gigi & Rp.34.000.000 \\
\hline 10. & Dental chair & Rp.190.000.000 \\
\hline 11. & Alat set diagnostik & Rp.14.600.000 \\
\hline 12. & Set exo & Rp.6.475.000 \\
\hline 13. & Set konservasi & Rp.7.600.000 \\
\hline 14. & Set perio & Rp.13.900.000 \\
\hline 15. & Set ortho & Rp.41.000.000 \\
\hline 16. & Set cetak & Rp.4.500.000 \\
\hline 17. & Set emergency kit & Rp.14.900.000 \\
\hline 18. & Set laboratorium gigi sederhana & Rp.34.000.000 \\
\hline 19. & Alat sterilisasi & Rp.19.500.000 \\
\hline & TOTAL & Rp.7.480.475.000 \\
\hline
\end{tabular}

Sumber: Dental Care \& Aesthetic Center, (2018)

Tabel diatas berisi perincian biaya peralatan dan perlengkapan yang diperlukan untuk pembukaan cabang baru didaerah Setiabudi pada kondisi ekonomi

dan politik memburuk, untuk daerah Menteng dan Kebon Jeruk, dan kondisi ekonomi dan politik stabil dan membaik akan peneliti cantumkan pada lampiran

Biaya Pembukaan Cabang Baru

\begin{tabular}{lccc}
\hline \multirow{1}{*}{ DAERAH } & \multicolumn{2}{c}{ KONDISI EKONOMI DAN POLITIK } \\
& $\begin{array}{c}\text { MEMBURUK } \\
\text { (Probabilitas : 0,3) }\end{array}$ & $\begin{array}{c}\text { STABIL } \\
\text { (Probabilitas : 0,45) }\end{array}$ & $\begin{array}{c}\text { MEMBAIK } \\
\text { (Probabilitas : 0,25) }\end{array}$ \\
\hline Setiabudi & Rp.7.480.475.000 & Rp.8.652.547.000 & Rp.8.038.000.000 \\
Menteng & Rp.8.580.475.000 & Rp.9.452.547.000 & Rp.7.638.000.000 \\
Kebon Jeruk & Rp.6.980.475.000 & Rp.7.952.547.000 & Rp.6.388.000.000 \\
\hline
\end{tabular}

Sumber: Dental Care \& Aesthetic Center, (2018)

Dalam penelitian ini peneliti menggunkan pendekatan subjektif dalam menentukan nilai probabilitas, bahwa besarnya nilai probabilitas didasarkan pada penilaian atau keyakinan pribadi dari pemilik Klinik. 


\section{Expected Value (EV)}

Perhitungan Expected Value :

- $\quad$ Setiabudi $\quad$ :Rp.7.480.475.000 $(0,3)+$ Rp.8.652.547.000 $(0,45)+$ Rp.8.038.000.000 $(0,25)=$ Rp.8.147.288.650

- Menteng : Rp.8.580.475.000 (0,3) + Rp.9.452.547.000 $(0,45)+$ Rp.7.638.000.000 $(0,25)=$ Rp.8.737.288.650

- Kebon Jeruk : Rp.6.980.475.000 (0,3) + Rp.7.952.547.000 (0,45) + Rp.6.388.000.000 $(0,25)=$ Rp.7.269.788.650

Dari perhitungan tersebut maka hasil keputusan untuk membuka cabang baru dengan kriteria Expected Value adalah di daerah Menteng.

\section{Expected Opportunity Loss (EOL)}

Perhitungan Payoff :

- Kondisi Ekonomi dan Politik Memburuk :

Setiabudi $\quad$ : Rp.8.580.475.000 - Rp.7.480.475.000 = Rp.1.100.000.000

Menteng : Rp.8.580.475.000 - Rp.8.580.475.000 = Rp.0

Kebon Jeruk : Rp.8.580.475.000 - Rp.6.980.475.000 = Rp.1.600.000.000

- Kondisi Ekonomi dan Politik Stabil :

Setiabudi $\quad$ : Rp.9.452.547.000 - Rp.8.652.547.000 = Rp.800.000.000

Menteng : Rp.9.452.547.000 - Rp.9.452.547.000 = Rp.0

Kebon Jeruk : Rp.9.452.547.000 - Rp.7.952.547.000 = Rp.1.500.000.000

- Kondisi Ekonomi dan Politik Membaik :

Setiabudi $\quad$ : Rp.8.038.000.000 - Rp.8.038.000.000 = Rp. 0

Menteng : :Rp.8.038.000.000 - Rp.7.638.000.000 = Rp.400.000.000

Kebon Jeruk : Rp.8.038.000.000 - Rp.6.388.000.000 = Rp. 1.650.000.000

\begin{tabular}{llllr}
\multicolumn{5}{c}{ Hasil Perhitungan Payoff } \\
DAERAH & \multicolumn{1}{c}{ MEMBURUK } & \multicolumn{1}{c}{ STABIL } & \multicolumn{1}{c}{ MEMBAIK } & \multicolumn{1}{c}{ PAYOFF } \\
Setiabudi & Rp.1.100.000.000 & Rp.800.000.000 & Rp.0 & Rp. 1.100 .000 .000 \\
Menteng & Rp.0 & Rp.0 & Rp.400.000.000 & Rp.400.000.000 \\
Kebon Jeruk & Rp.1.600.000.000 & Rp.1.500.000.000 & Rp. 1.650 .000 .00 & Rp. 1.650 .000 .00
\end{tabular}

Sumber: Data diolah oleh peneliti (2018)

Perhitungan Expected Opportunity Loss :

- Setiabudi : Rp.1.100.000.000 $(0,3)+$ Rp.800.000.000 $(0,45)+R p .0(0,25)=$ Rp.690.000.000

- Menteng : Rp.0 (0,3)+Rp.0 (0,45)+Rp.400.000.000 (0,25) = Rp.100.000.000

- Kebon Jeruk : Rp.1.600.000.000 (0,3) + Rp.1.500.000.000 (0,45) +

Rp.1.650.000.000 $(0,25)=$ Rp.1.567.500.000

Dari perhitungan tersebut maka hasil keputusan untuk membuka cabang baru dengan kriteria Expected Opportunity Loss adalah di daerah Menteng.

\section{Maximax}

Biaya Pembukaan Cabang Baru

\begin{tabular}{lrr}
\hline \multicolumn{1}{c}{ DAERAH } & BIAYA \\
Setiabudi & Rp.8.652.547.000 \\
Menteng & Rp.10.052.547.000 \\
Kebon Jeruk & Rp.7.952.547.000
\end{tabular}

Sumber: Data diolah oleh peneliti (2018) 
Hasil keputusan berdasarkan kriteria Maximax adalah membuka cabang baru di daerah Menteng.

\section{Maximin}

Biaya Pembukaan Cabang Baru

\begin{tabular}{|c|c|}
\hline DAERAH & BIAYA \\
\hline Setiabudi & Rp.7.480.475.000 \\
\hline Menteng & Rp.7.638.000.000 \\
\hline Kebon Jeruk & Rp.6.388.000.000 \\
\hline
\end{tabular}

Sumber: Data diolah oleh peneliti (2018)

Hasil keputusan berdasarkan kriteria Maximin adalah membuka cabang baru di daerah Menteng.

\section{Minimax Regret}

Perhitungan Payoff :

- Kondisi Ekonomi dan Politik Memburuk :

Setiabudi $\quad:$ Rp.8.580.475.000 - Rp.7.480.475.000 = Rp.1.100.000.000

Menteng : Rp.8.580.475.000 - Rp.8.580.475.000 = Rp.0

Kebon Jeruk $\quad$ : Rp.8.580.475.000 - Rp.6.980.475.000 = Rp.1.600.000.000

- Kondisi Ekonomi dan Politik Stabil :

Setiabudi $\quad$ : Rp.9.452.547.000 - Rp.8.652.547.000 = Rp.800.000.000

Menteng $\quad$ :Rp.9.452.547.000 - Rp.9.452.547.000 = Rp.0

Kebon Jeruk : Rp.9.452.547.000 - Rp.7.952.547.000 = Rp.1.500.000.000

- Kondisi Ekonomi dan Politik Membaik :

Setiabudi $\quad$ : Rp.8.038.000.000 - Rp.8.038.000.000 = Rp.0

Menteng : Rp.8.038.000.000 - Rp.7.638.000.000 = Rp.400.000.000

Kebon Jeruk $\quad$ : Rp.8.038.000.000 - Rp.6.388.000.000 = Rp. 1.650.000.000

\section{Hasil Perhitungan Payoff}

\begin{tabular}{|c|c|c|c|c|}
\hline DAERAH & MEMBURUK & STABIL & MEMBAIK & PAYOFF \\
\hline Setiabudi & Rp.1.100.000.000 & Rp.800.000.000 & Rp.0 & Rp.1.100.000.000 \\
\hline Menteng & Rp.0 & Rp.0 & Rp.400.000.000 & Rp.400.000.000 \\
\hline Kebon Jeruk & Rp.1.600.000.000 & Rp.1.500.000.000 & Rp. 1.650 .000 .00 & Rp. 1.650 .000 .00 \\
\hline
\end{tabular}

Sumber: Data diolah oleh peneliti (2018)

Hasil keputusan berdasarkan kriteria

Minimax Regret adalah membuka cabang

baru di daerah Menteng.

Equal Likelihood

Perhitungan Equal Likelihood:

- Setiabudi : Rp.7.480.475.000 (0,33) + Rp.8.652.547.000 $(0,33)+$

Rp.8.038.000.000 (0,33) = Rp.7.976.437.260 
- $\quad$ Menteng : Rp.8.580.475.000 (0,33) + Rp.9.452.547.000 $(0,33)+$ Rp.7.638.000.000 $(0,33)=$ Rp.8.471.437.260

- Kebon Jeruk : Rp.6.980.475.000 (0,33) + Rp.7.952.547.000 $(0,33)+$ Rp.6.388.000.000 $(0,33)=$ Rp.7.035.937.260

Dari perhitungan tersebut maka hasil keputusan untuk membuka cabang baru dengan kriteria Euqual Likelihood adalah di daerah Menteng.

\section{Decision Tree (Pohon Keputusan)}

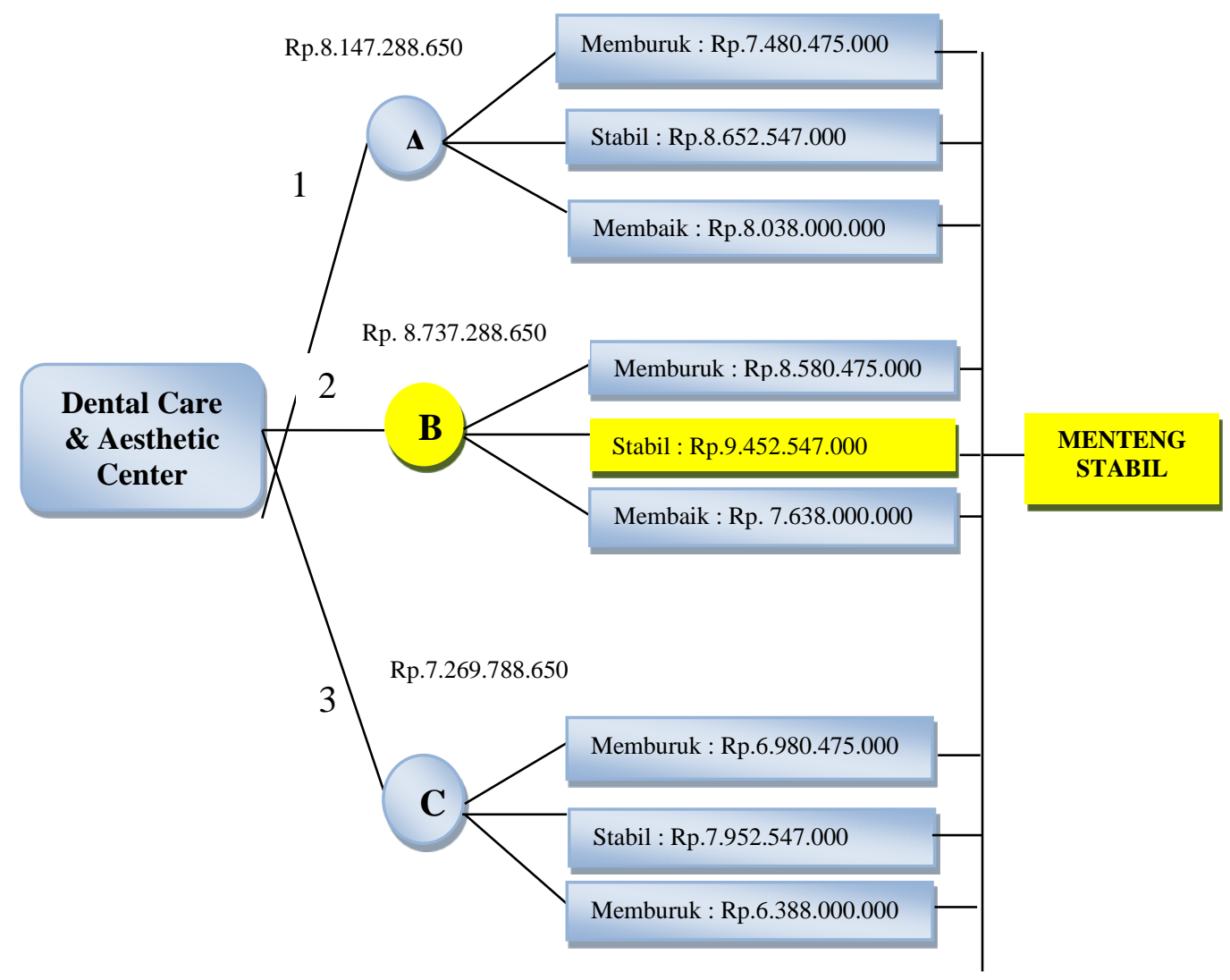

Sumber : Data diolah peneliti (2018)

Keterangan : (1). Setiabudi; (2). Menteng; (3). Kebon Jeruk

\section{Perhitungan dengan QM For Windows}

Hasil Perhitungan Penentuan Pembukaan Cabang Baru Dental Care \& Aesthetic Center dengan QM For Windows

\begin{tabular}{|c|c|c|c|c|c|}
\hline & Memburuk & Stabil & Membalk & Row Min & Row Max \\
\hline Probablities & 0 . & o, & 0. & & \\
\hline Setiabudi & 7.480 .475 .000 & 8.652 .547 .000 & 8.038 .000 .000 & 7.480 .475 .000 & 8.652 .547 .000 \\
\hline Menteng & 8.580 .475 .000 & 9.452 .547 .000 & 7.638 .000 .000 & 7.638 .000 .000 & 9.452 .547 .000 \\
\hline \multirow[t]{3}{*}{ Kebon Jeruk } & 6.980 .475 .000 & 795.25 .700 & 6.388 .000 .000 & 795.25 .4 .700 & 6.980 .475 .000 \\
\hline & & & maximum & 7.638 .000 .000 & $9,452.547 .000$ \\
\hline & & & & maximin & $\max i m a x$ \\
\hline
\end{tabular}

Sumber: data diolah oleh peneliti (2018) 
Dari keenam kriteria perhitungan manual dan perhitungan dengan menggunakan $Q M$ For Windows, diketahui semua kriteria memiliki hasil keputusan yang sama yaitu membuka cabang baru di daerah Menteng, jadi keputusan terbaik untuk membuka cabang baru adalah daerah Menteng.

\section{IMPLIKASI HASIL PENELITIAN Implikasi Hasil Penelitian Secara}

\section{Teoritis}

1. Melalui perhitungan tujuh metode forecasting secara manual maupun dengan aplikasi $Q M$ For Windows didapatkan hasil MAD dan MSE terkecil dari metode Multiplicative Decomposition Average All yaitu dengan MAD sebesar 39,6634 dan MSE sebesar 2.305,762, maka dapat digunakan metode Multiplicative Decomposition Average All untuk perhitungan forecasting selanjutnya. Temuan ini sesuai dengan penelitian yang dilakukan oleh Djie (2013) dalam jurnal The Winners Volume 14, No.2 September 2013, Metode yang digunakan dalam penelitian ini adalah metode peramalan, di antaranya adalah naive method, moving average, weighted moving averages, exponential smoothing, exponential smoothing with trend, dan regresi linear. Dari hasil penelitian ini didapatkan bahwa regresi linear merupakan metode yang paling tepat dalam menentukan peramalan permintaan pada periode berikutnya karena memiliki nilai MAD dan MSE terkecil.
Temuan ini didukung oleh penelitian yang dilakukan oleh Sarjono dkk (2013) dalam jurnal Binus Business Review Volume 4, No. 2 November 2013, dari hasil penelitian yang menggunakan 11 metode forecasting tersebut didapat MAD terkecil sebesar 101,69 dan MSE terkecil sebesar 15.163,95. Pada metode additive decomposition- average all menunjukkan bahwa data tersebut memperlihatkan peramalan jumlah tamu yang menginap di Hotel Karlita Internatioanl pada periode Juni 2013 sebesar 960 tamu.

2. Melalui perhitungan dengan metode Decision Tree, hasil penelitian ini menunjukkan bahwa keputusan terbaik untuk membuka cabang baru Dental Care \& Aesthetic Center adalah di daerah Menteng, dengan nilai harapan (expected value) sebesar Rp.9.452.547.000. Temuan ini didukung oleh Djie (2013) dalam jurnal The Winners Volume 14, No.2 September 2013, dari hasil penelitian ini didapatkan bahwa berdasarkan perhitungan, nilai harapan (expected value) B2 lebih besar daripada B1. Hal ini menunjukkan bahwa keuntungan yang didapatkan perusahaan lebih besar jika memilih alternatif B2. Oleh karena itu, bahwa berdasarkan pohon keputusan, alternatif yang sebaiknya dipilih oleh perusahaan adalah alternatif B2, yaitu meningkatkan kapasitas produksi. Temuan ini didukung dengan adanya data-data penduduk dan geografis daerah Menteng, sebagai berikut: 
Presentase Luas Wilayah Menurut Kelurahan 2017

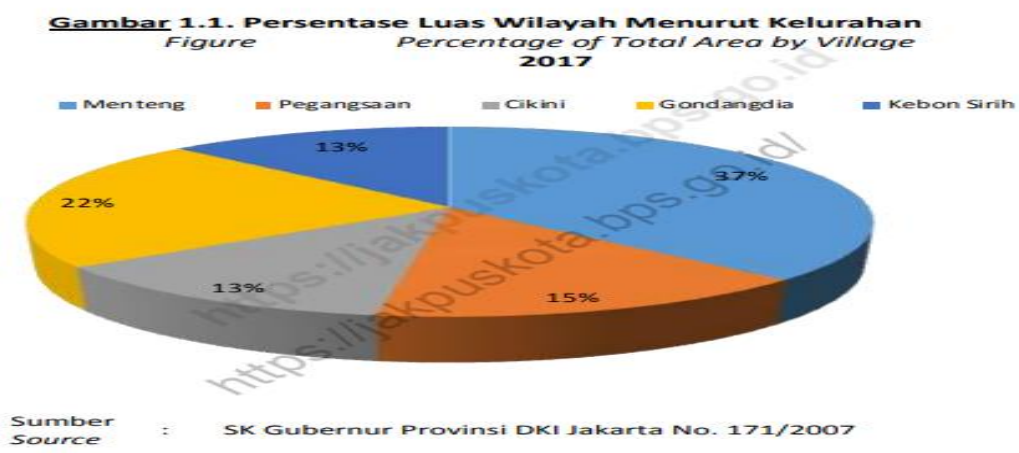

Sumber : $\underline{w w w . b p s . g o . i d}$

Presentase Luas Wilayah Menurut Kelurahan 2017

Tabel

Table

1.1 Luas Wilayah Menurut Kelurahan

1 Total Area by Village

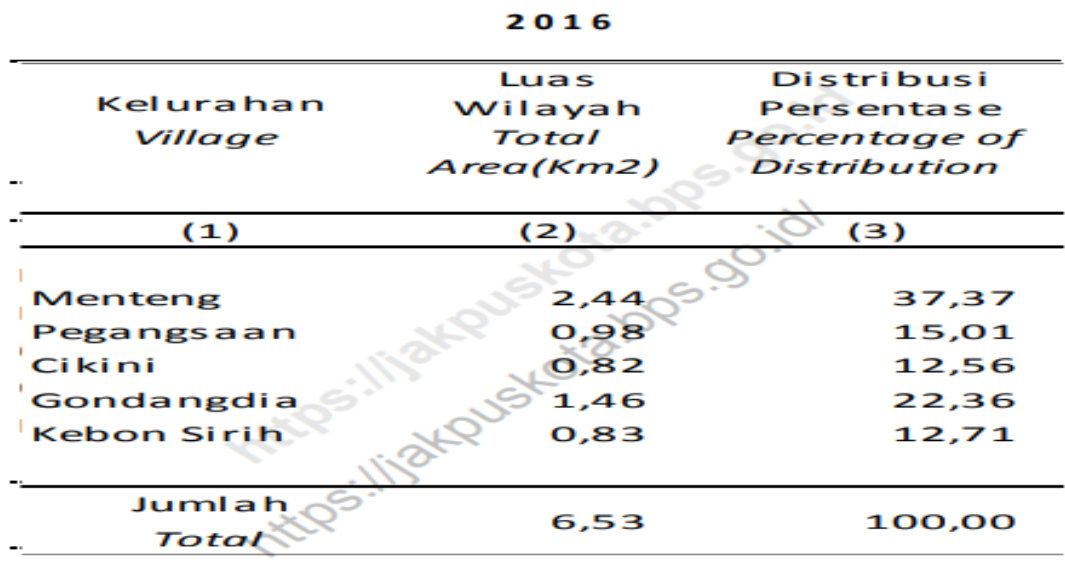

Sumber SK Gubernur Provinsi DKI Jakarta No. 171/2007

Sumber: $\underline{\text { www.bps.go.id }}$

Dari gambar diatas dapat dilihat bahwa

Jakarta Pusat yang memiliki presentase kelurahan Menteng merupakan daerah di luas wilayah paling besar yaitu $37 \%$.

\section{Luas Wilayah, Jumlah RT, RW, Rumah Tangga dan Penduduk} Menurut Kelurahan

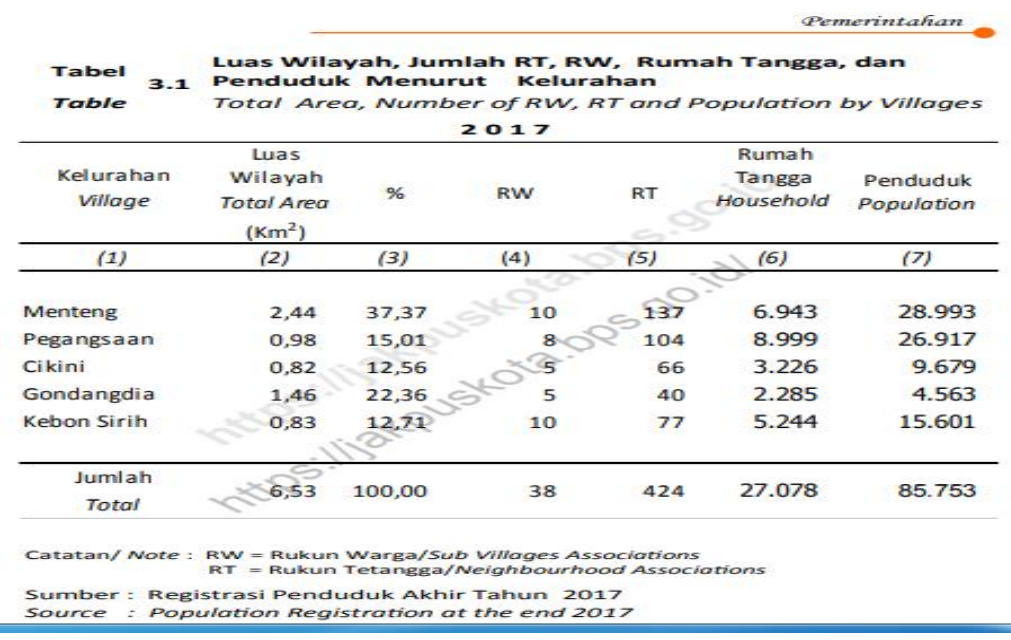

Sumber : www.bps.go.id (2018) 
Dari gambar diatas dapat dilihat bahwa Menteng merupakan kelurahan dengan populasi penduduk paling banyak yaitu sebesar 28.933 penduduk. Dari data dan hasil penelitian tersebut maka Menteng adalah tempat yang layak untuk dijadikan solusi keputusan pembukaan cabang baru.

Berdasarkan wawancara dengan bebrapa pihak yaitu pemilik klinik Dental Care \& Aesthetic Center, pemilik klinik dental lain yaitu klinik Bianz Dental Care dan pemilik ruko setempat, peneliti mendapatkan pendapat tentang pembukaan cabang baru didaerah Menteng dengan alamat J1. Tambak Raya, Menteng Jakarta Pusat. Berdasarkan wawancara dengan pemilik ruko setempat, lokasi ini merupakan lokasi yang strategis, ramai dan dekat dengan fasilitas umum, sehingga peneliti menyarankan ruko tersebut sebagai alternatif tempat untuk pembukaan cabang baru.

Berikut ini adalah hasil wawancara yang penelitu dapatkan, yaitu sebagai berikut :

1. Hasil wawancara dengan pemilik Dental Care \& Aesthetic Center

Dari wawancara yang dilakukan dengan pemilik Dental Care \& Aesthetic Center, peneliti mendapatkan jawaban bahwa pemilik kurang setuju, karena Menteng merupakan salah satu kawasan elit atau mahal, pemilik menjelaskan bahwa rharga ruko didaerah Menteng termasuk tinggi jika dibandingkan dengan daerah lainnya, semakin tinggi biaya yang dikeluarkan, maka akan semakin menambah tinggi harga perawatan atau pelayanan yang

\section{KESIMPULAN DAN SARAN}

Dari hasil penelitian, maka dapat ditarik beberapa simpulan sebagai berikut :

1. Forecasting

Melalui perhitungan tujuh metode forecasting secara manual maupun dengan aplikasi QM For Windows didapatkan hasil MAD dan MSE terkecil dari metode Multiplicative akan kita berikan, sehingga akan berdampak kepada minat pasien untuk melakukan perawatan di Dental Care \& Aesthetic Center.

2. Hasil wawancara dengan pemilik Bianz Dental Care

Dari wawancara yang dilakukan dengan pemilik Bianz Dental Care, peneliti mendapatkan jawaban yang sama dengan pemilik Dental Care \& Aesthetic Center, yaitu bahwa pemilik kurang setuju, dengan alasan yang hampir sama seperti yang dijelaskan oleh pemilik Dental Care \& Aesthetic Center, yaitu bahwa Menteng merupakan salah satu kawasan elit atau mahal, pemilik menjelaskan bahwa harga ruko didaerah Menteng termasuk tinggi jika dibandingkan dengan daerah lainnya, semakin tinggi biaya yang dikeluarkan, maka akan semakin menambah tinggi harga perawatan atau pelayanan yang akan kita berikan, sehingga akan berdampak kepada minat pasien untuk melakukan perawatan.

4. Hasil wawancara dengan sesama pemilik ruko setempat

Dari wawancara yang dilakukan dengan pemilik ruko setempat, peneliti mendapatkan jawaban bahwa pemilik setuju, dengan alasan bahwa ruko tersebut berada didaerah yang strategis dan ramai, ruko tersebut juga terletak didaerah yang dekat dengan fasilitas umum, sehingga lebih mudah untuk dijangkau konsumen.

Decomposition Average All yaitu dengan MAD sebesar 39,6634 dan MSE sebesar 2.305,762 dan hasil forecasting untuk periode selanjutnya adalah 293,0415, maka dapat digunakan metode Multiplicative Decomposition Average All untuk perhitungan forecasting selanjutnya. 
Hasil perhitungan secara manual maupun melalui QM For Windows tidak berbeda jauh, namun tetap ada perbedaan. Dimana perbedaan tersebut karena adanya pembulatan pada perhitungan manual, sedangkan $Q M$ For Windows tidak ada pembulatan.

2. Keputusan pembukaan cabang baru didaerah yang paling berpotensi dengan tujuan agar bertambahnya pasien yang berkunjung di Dental Care $\&$ Aesthetic Center.

3. Decision Tree

Dari hasil perhitungan dengan metode Decision Tree baik secara manual dan dengan QM For Windows keputusan membuka cabang baru didaerah potensi, hasil yang paling maksimal yaitu membuka cabang baru didaerah Menteng, Jakarta Pusat, dengan nilai harapan (Expected Value) sebesar Rp.9.452.547.000.

Berikut ini beberapa saran yang dapat diberikan kepada klinik Dental Care \& Aesthetic Center adalah sebagai berikut :

1. Setelah melakukan analisis peramalan jumlah pasien yang berkunjung pada bulan November 2018, perkembangan jumlah pasien terlihat semakin meningkat.

\section{DAFTAR PUSTAKA}

Athoillah, Anton. 2010. Dasar-Dasar Manajemen. Pustaka Setia, Bandung.

Augusty, Ferdinand. 2017. Metode Penelitian Manajemen. Badan Penerbit Universitas Diponegoro, Semarang.

Cooper, Donald R. Dan Pamela S. Schindler. 2017. Metode Penelitian Bisnis Buku 1.

Salemba Empat, Jakarta.

Djie, Inti Sariani Jianta. 2013. Analisis Peramalan Penjualan Dan Pengunaan Metode Linear Progamming dan Decision Tree Guna Mengoptimalkan Keuntungan Pada PT Primajaya Pantes Garment. Vol.14 No.2. Jakarta : Universitas Bina Nusantara.

Effendi, Usman. 2014. Asas Manajemen. Rajagrafindo Persada, Depok.

Heizer, Jay dan Barry Render. 2009. Manajemen Operasi Buku 1 Edisi 9. Salemba Empat, Jakarta.

Heizer, Jay dan Barry Render. 2017. Manajemen Operasi: Keberlangsungan dan Rantai Pasokan. Cetakan ke-3. Salemba Empat, Jakarta.

Herjanto, Eddy dan Djony Herfan. 2007. Manajemen Operasi Edisi 3. Grasindo, Jakarta. 
Manullang, Laurence A. 2014. Teori Aplikasi Manajemen: Komprehensif Integralistik. Mitra Wacana Media, Jakarta.

Martiningtyas, Nining. 2004. Buku Materi Kuliah STIKOM Statistika. STIKOM Surabaya, Surabaya.

Marsetiani, Marcella. 2014. Model Optimasi Kombinasi Produk Menggunalan Metode Linear Progamming Pada Perusahaan Bidang Fashion. Vol.14 No.2. Jakarta : Universitas Bina Nusantara.

Rangkuti, Freddy. 2005. Business Plan: Teknik Membuat Perencanaan Bisnis \& Analisis Kasus. Gramedia Pustaka Utama, Jakarta.

Saptria, Lina Nurhidayati. 2017. Analisis Peramalan Permintaan Produk Nata De Coco Untuk Mendukung Perencanaan Dan Pengendalian Produksi Dalam Supply Chain Dengan Model CPFR (Collaborative, Planning, Forecasting, And Replenishment). Vol.2 No.2. Kediri: Universitas Nusantara PGRI.

Sarjono, Haryadi. 2014. Aplikasi Riset Operasi. Salemba Empat, Jakarta.

Sarjono, Haryadi dan Bachtiar Saleh Abbas. 2017. FORECASTING: Aplikasi Penelitian Bisnis QM For Windows vs Minitab vs Manual. Mitra Wacana Media, Jakarta.

Sarjono, Haryadi dan Irwan Zulkifli. 2013. Prediksi Jumlah Tamu Menginap Di Hotel

Karlita International, Tegal, Jawa Tengah. Jakarta: Universitas Bina Nusantara.

Subagyo, Joko P. 2006. Metode Penelitian Dalam Teori dan Praktek. Rineka Cipta, Jakarta.

Sudaryono. 2012. Statistika Probabilitas (Teori dan Aplikasi). Andi. Yogyakarta

Sugiyono. 2017. Metode Penelitian Kuantitatif, Kualitatif dan R\&D. Alfabeta, Bandung.

Supranto, J. 2001. Statistik Teori dan Aplikasi Edisi 6. Erlangga, Jakarta.

Tampubolon, Manahan P. 2018. Manajemen Operasi dan Rantai Pasokan Edisi Revisi. Mitra Wacana Media, Jakarta.

Usman, Husaini. 2016. Manajemen: Teori, Praktik dan Riset Pendidikan. Bumi Aksara, Jakarta.

Widodo, Prabowo Pudjo dkk. 2013. Data Mining: Artificial Intelligence, Special Computer Methods. Rekayasa Sains, Bandung.

(ON-LINE) : unpad.ac.id (20 Januari 2018)

(ON-LINE) : www.depkes.go.id (20 Januari 2018)

(ON-LINE) : www.detik.com (22 Januari 2018)

(ON-LINE) : www.jakarta.bps.go.id (2 Februari 2018)

(ON-LINE) : www.jakbarkota.bps.go.id (3 Februari 2018)

(ON-LINE) : www.kompas.com (5 Februari 2018)

(ON-LINE) : www.okezone.com (10 Februari 2018)

(ON-LINE) : www.swa.co.id (11 Februari 2018) 